\title{
THE RELATIONSHIP BETWEEN INSTITUTIONAL ENVIRONMENT, GUARDIAN INVOLVEMENT, ACADEMIC ACHIEVEMENT AND LEARNING MOTIVATION OF CHILDREN REARED IN A MALAYSIAN ORPHANAGE
}

\author{
A.J. Alfred, A.M. Ma'rof, N. Buang \\ Faculty Educational Studies, University of Putra Malaysia \\ norazirahbuang@gmail.com
}

\begin{abstract}
This research was conducted to study the relationships between academic performance, learning motivation, institutionalised environments and guardian involvement of children reared in a Malaysian orphanage. This study involves 50 students consisting of 21 female and 29 male students. These students are in secondary school with ages ranging from 13-17 years old. This study was conducted in a home for orphans and under-privileged children and all the participants of this study are from this home. The findings of this study show that there is a significant relationship between academic performance, intrinsic motivation, extrinsic motivation and therefore learning motivation as a whole $(P<0.05)$. Findings also show that there is strong correlation between guardian involvement and academic performance $(P<0.05)$. However for relationships between guardian involvement and learning motivation, institutionalised environment and academic performance and institutionalised environment and guardian involvement, correlations fail to exist $(P>0.05)$.
\end{abstract}

Keywords: learning motivation, institutionalised environments, guardian involvement, academic achievement

\section{Introduction}

Institutional organisations such as orphanages usually have the sole purpose of rearing children who have lost the privilege of being brought up by their biological parents due to unforeseen circumstances. These institutions rear orphaned children with the hope of providing them with a better home environment in order for them to become useful people in their society. Although most of them do make it in life, poor academic achievement has been found in both children in orphanages and children after adaption from orphanage (Maclean, 2003). This growing issue of institutionalised children falling back in their academic achievements is also prevalent in Malaysia. Despite the dramatic growth in the country's overall educational attainment, the fact remains that there still exists a huge educational gap between the mainstream and the underserved populations in the country that cannot be ignored (Ma'rof, 2012). Therefore, this study hopes to find ways to improve the institutional environment of an orphanage in Malaysia in order to improve the academic performances of the children reared in it. The children reared in this orphanage have not necessarily lost their parents by death. Some of them have divorced parents while some of them have lost one parent due to death. The reason for them being reared in this home is most probably because the single parent (usually the mother) is not financially stable and cannot provide for her children.

\section{Method}

\section{A. Participants}

The population of the study is the secondary school going children of the chosen orphanage. The whole population participated in this study. The total numbers 
of participants of this study were 50 students consisting of 29 male and 21 female students. All the participants that took part were secondary school children therefore their ages were from 13 years to 17 years old. Some of the children that took part were orphaned while the most of them have at least one parent that is still alive. The participants of the study have been institutionalised different amounts of years.

\section{B. Instruments}

1. Guardian Involvement Survey

The Guardian Involvement Survey was adapted from Family Involvement Survey which was designed by Daleure, G.,Albon, R.,Hinkston, K.,Ajaif, T., and McKeown, J. In their research paper, Home Environment, Family Involvement, and Emirati College Student Academic Achievement this instrument was validated. Upon compilation of the instrument, it was reviewed for cultural sensitivity by an Emirati research team member who was the Dean of Student Services at that time. Validation for The Guardian Involvement Survey was piloted with a mixed gender group of 37 students, modified and administered again with ten different students, the loaded into an online delivery system and was made accessible through the college portal. Consent to use this instrument was given by the author Georgia Deleure herself through an e-mail. In order to ensure the validity of the instrument, a pilot study was conducted and the results showed that the instrument had a validity of $\alpha=0.81$.

\section{Academic Motivational Scale}

The high school version of the Academic Motivational Scale was used to measure the participant's learning motivation. The Academic Motivational Scale consists of 28 statements where participants have to choose a number from 1 to 5,1 indicating strongly disagree, 2 indicating disagree, 3 indicating neutral, 4 indicating agree and 5 indicating strongly agree. This scale measures three kinds of intrinsic motivation, three kinds of extrinsic motivation and amotivation. The three kinds of intrinsic motivation are "motivated to know", "motivated towards accomplishments" and "motivated to experience stimulation", while the three kinds of extrinsic motivation are "identified motivation", "introjected motivation" and "external regulation motivation". Consent to use this instrument is given to the public as long as complete reference data is mentioned. In order to ensure the validity of the instrument, a pilot study was conducted and the results showed that the instrument had a validity of $\alpha=0.86$.

Table 1: Statistical Analysis

\begin{tabular}{ll}
\hline \multicolumn{1}{c}{ Research Question } & \multicolumn{1}{c}{ Statistical Analysis } \\
\hline What is the level of student academic achievement of children & Mean and Standard Deviation \\
reared in the orphanage? & \\
What is the level of guardian involvement in the orphanage? & Mean and Standard Deviation \\
What is the level of learning motivation of children reared in & Mean and Standard Deviation \\
the orphanage? & \\
What is the level of institutional environment of children & Mean and Standard Deviation \\
reared in the orphanage? & \\
What is the statistical association between Learning Motivation & \\
and Academic Performance? & \\
What is the statistical association between Guardian & \\
Involvement and Academic Performance? & \\
What is the statistical association between Guardian & Pearson Correlation \\
Involvement and Learning Motivation? & \\
What is the statistical association between Institutional & Pearson Correlation \\
Environment and Academic Performance? & \\
What is the statistical association between Institutional & Pearson Correlation \\
Environment and Learning Motivation? &
\end{tabular}




\section{Data analysis procedure}

Statistical analysis using SPSS was done to answer the following research questions.

\section{Result}

\section{Participants Gender}

Table 2 shows that there were more male participants $(58 \%)$ compared to female participants $(42 \%)$ in the study.

Table 2: Participant's Gender

\begin{tabular}{lcc}
\hline \multicolumn{1}{c}{ Gender } & Frequency & Percent $(\%)$ \\
\hline Female & 21 & 42 \\
Male & 29 & 58 \\
Total & 50 & 100 \\
\hline
\end{tabular}

\section{Participants Age}

Figure 1 shows that the age of the respondents ranged from between 13 to 17 years old. Majority of the participants were 17 years old $(28 \%)$, followed by the 14 year olds $(24 \%)$, and there were an equal number of 13,15 and 16 year olds (16\%) respectively.

From Figure 1 we can see that the distribution of ages among participants is evenly distributed.

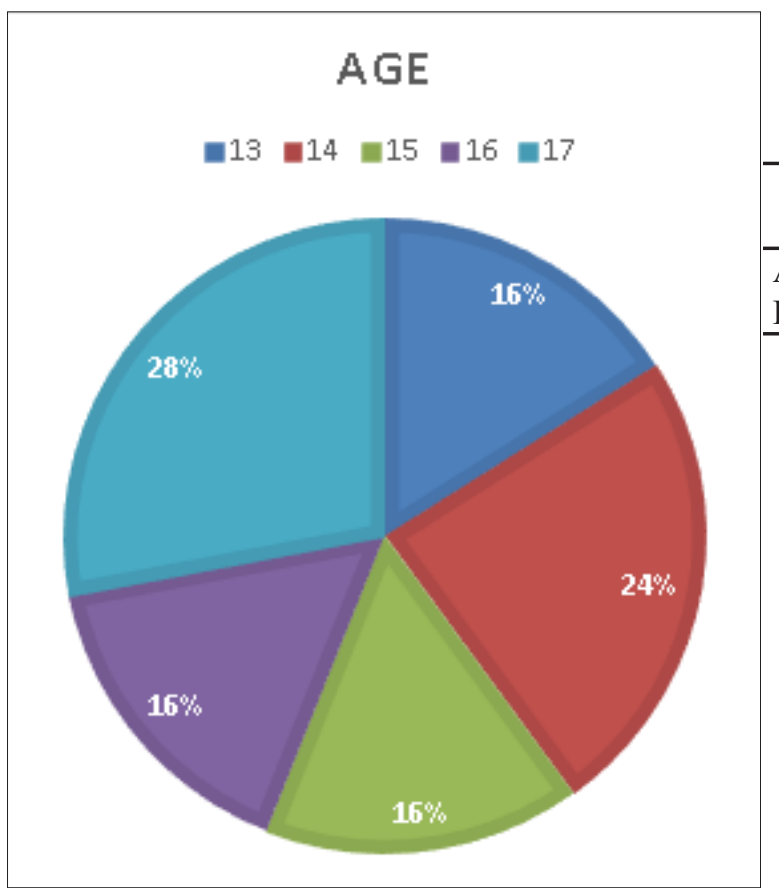

Figure 1: Participant's Age
3. The level of student academic achievement of children reared in the orphanage

According to Majlis Peperiksaan Malaysia (MPM), students are graded according to the marks in the table below. Table 2 shows how Malaysian students are graded.

Table 3: Malaysian Schools Grading Scale

\begin{tabular}{ccc}
\hline Grade & Scale & Grade Description \\
\hline A & $75.00-100$ & Distinction \\
B & $60.00-74.99$ & Credit \\
C & $50.00-59.99$ & Pass \\
D & $40.00-49.99$ & Pass \\
F & $0.00-39.99$ & Fail \\
\hline
\end{tabular}

Table 4 shows the overall level of academic performance of the students. The data shows that the minimum marks obtained by the participants in the study is $10 \%$, while the maximum marks obtained is $72 \%$ which is not even an A according to the grading table. The overall mean for academic performance of the students is very low $(\mathrm{M}=37.7)$ while the standard deviation is high $(\mathrm{SD}=19.5)$. The analysis shows that the overall performance for academic achievement is very poor.

Table 4: Academic Performance

\begin{tabular}{|c|c|c|c|c|}
\hline & Minimum & Maximum & Mean & $\begin{array}{l}\text { Standard } \\
\text { Deviation }\end{array}$ \\
\hline $\begin{array}{l}\text { Academic } \\
\text { Performance }\end{array}$ & 10.0 & 72.0 & 37.7 & 19.5 \\
\hline
\end{tabular}

Therefore, the level of student academic achievement of student reared in the orphanage is very low as the mean mark is only $37.7 \%$ which is in the category of "Fail".

\section{The level of guardian involvement in the orphanage \\ Students had to answer the questionnaire by choosing a number on the likert scale where 1 = Strongly Disagree, $2=$ Disagree, 3 $=$ Agree, and $4=$ Strongly Agree .}


Table 5: Guardian Involvement

\begin{tabular}{ccc}
\hline & Mean & $\begin{array}{c}\text { Std. } \\
\text { Deviation }\end{array}$ \\
\hline $\begin{array}{c}\text { Guardian } \\
\text { Involvement }\end{array}$ & 1.9575 & 0.20864 \\
\hline
\end{tabular}

As we can see from Table 5, most of the students choose the option "Strongly Disagree" and "Disagree" since a very low mean was achieved $(\mathrm{M}=1.9575, \mathrm{SD}=0.20864)$. Therefore the level of guardian involvement in the orphanage is low.

\section{The level of learning motivation of children reared in the orphanage}

To determine the level of student's motivation, the participants had to answer a 5 likert scale questionnaire. Where $1=$ Strongly Disagree, 2=Disagree, 3=Neutral, 4=Agree, $5=$ Strongly agree. Options 1 and 2 indicated a low level of motivation, while option 3 a moderate level of motivation and options 4 and 5 indicated a high level of motivation.

\section{Intrinsic Motivation}

Table 6 shows the overall results for intrinsic motivation had a mean of 2.7604 and a standard deviation of 1.4266 .

Table 6: Intrinsic Motivation

\begin{tabular}{ccc}
\hline $\begin{array}{c}\text { Intrinsic } \\
\text { Motivation }\end{array}$ & Mean & $\begin{array}{c}\text { Std. } \\
\text { Deviation }\end{array}$ \\
\hline $\begin{array}{c}\text { Overall } \\
\text { Results }\end{array}$ & 2.7604 & 1.4266 \\
\hline
\end{tabular}

\section{Extrinsic Motivation}

Table 7 shows he overall results for extrinsic motivation had a relatively high mean $(\mathrm{M}=3.7937, \mathrm{SD}=0.8656)$.

Table 7: Extrinsic Motivation

\begin{tabular}{ccc}
\hline $\begin{array}{c}\text { Extrinsic } \\
\text { Motivation }\end{array}$ & Mean & $\begin{array}{c}\text { Std. } \\
\text { Deviation }\end{array}$ \\
\hline $\begin{array}{l}\text { Overall } \\
\text { Results }\end{array}$ & 3.7937 & 0.8656 \\
\hline
\end{tabular}

\section{Learning Motivation}

Table 8 shows that the overall mean for learning motivation is higher $(\mathrm{M}=3.2771$,
$\mathrm{SD}=1.09305)$ than the overall mean for intrinsic motivation but lower than the overall mean for extrinsic motivation.

Table 8: Learning Motivation

\begin{tabular}{lcc}
\hline & Mean & Std. Deviation \\
\hline $\begin{array}{l}\text { L e a r n i n g } \\
\text { Motivation }\end{array}$ & 3.2771 & 1.09305 \\
\hline
\end{tabular}

Therefore, the children reared in the orphanage have a moderate level of motivation. However, it is evident that the children have a very low intrinsic motivation but due to their higher levels of extrinsic motivation, the overall score for Learning Motivation is moderate.

\section{The level of Institutional Environment of children reared in the orphanage}

To find out the level of institutional environment, the children answered a 4 likert scale. Students had to answer the questionnaire by choosing a number on the likert scale where $1=$ Strongly Disagree, $2=$ Disagree, $3=$ Agree, and $4=$ Strongly Disagree.

Table 9 shows that the mean obtained for 'Home Environment' is 3.2870 with a standard deviation of 0.10174 . The mean of 3.2870 shows that most of the students choose the option 'Agree' and are somewhat satisfied with the condition of their institutional environment.

Table 9 Institutional Environment

\begin{tabular}{lcc}
\hline & Mean & Std. Deviation \\
\hline Institutional & 3.2870 & 0.10174 \\
Environment & & \\
\hline
\end{tabular}

Therefore, the result shows that the level of the institutional environment is high.

\section{The statistical association between Learning Motivation and Academic Performance}

Table 10 shows that there is a significant positive correlation between Academic Performance and Intrinsic Motivation ( $\mathrm{P}<$ 0.01). 
Table 10 Pearson- Correlation of Academic Performance and Intrinsic Motivation

\begin{tabular}{llcc}
\hline & & Intrinsic Motivation & $\begin{array}{c}\text { Academic } \\
\text { Performance }\end{array}$ \\
\hline \multirow{2}{*}{ Intrinsic Motivation } & $\begin{array}{l}\text { Pearson Correlation } \\
\text { Significant (2-tailed) } \\
\text { Academic Performance }\end{array}$ & 1 & $0.860^{* *}$ \\
& $\begin{array}{l}\text { Pearson Correlation } \\
\text { Significant (2-tailed) }\end{array}$ & $0.860 * *$ \\
& $* *$ Correlations is significant at the 0.01 level (2- tailed) & 1 \\
\hline \multicolumn{4}{c}{0.000} \\
\end{tabular}

Table 11: Pearson- Correlation of Academic Performance and Extrinsic Motivation

\begin{tabular}{llcc}
\hline & & Academic Performance & Extrinsic Motivation \\
\hline \multirow{2}{*}{ Academic Performance } & Pearson Correlation & 1 & $0.844^{* *}$ \\
& Significant (2-tailed) & & 0.000 \\
\multirow{2}{*}{ Extrinsic Motivation } & Pearson Correlation & $0.844^{* *}$ & 1 \\
& Significant (2-tailed) & 0.000 & \\
\hline & $* *$ Correlations is significant at the 0.01 level (2- tailed)
\end{tabular}

Table 12: Pearson- Correlation of Academic Performance and Learning Motivation

\begin{tabular}{llcc}
\hline & & Academic Performance & Learning Motivation \\
\hline \multirow{2}{*}{ Academic Performance } & Pearson Correlation & 1 & $0.895^{* *}$ \\
& Significant (2-tailed) & & 0.000 \\
\multirow{2}{*}{ Learning Motivation } & Pearson Correlation & $0.895^{* *}$ & 1 \\
& Significant (2-tailed) & 0.000 &
\end{tabular}

Table 13: Pearson- Correlation of Academic Performance and Guardian Involvement

\begin{tabular}{llcc}
\hline & & Academic Performance & $\begin{array}{c}\text { Guardian } \\
\text { Involvement }\end{array}$ \\
\hline \multirow{2}{*}{ Academic Performance } & $\begin{array}{l}\text { Pearson Correlation } \\
\text { Significant (2-tailed) }\end{array}$ & 1 & $0.384^{*}$ \\
Guardian Involvement & $\begin{array}{l}\text { Pearson Correlation } \\
\text { Significant (2-tailed) }\end{array}$ & $0.384^{*}$ & 1 \\
& $*$ Correlations is significant at the level 0.05 (2-tailed) & \\
\hline
\end{tabular}

Table 14: Pearson- Correlation of Learning Motivation and Guardian Involvement

\begin{tabular}{llcc}
\hline & & Learning Motivation & $\begin{array}{c}\text { Guardian } \\
\text { Involvement }\end{array}$ \\
\hline \multirow{2}{*}{ Learning Motivation } & Pearson Correlation & 1 & 0.275 \\
& Significant (2-tailed) & & 0.086 \\
Guardian Involvement & Pearson Correlation & 0.275 & 1 \\
& Significant (2-tailed) & 0.086 & 1 \\
\hline
\end{tabular}

Table 15: Pearson- Correlation of Learning Motivation and Guardian Involvement

\begin{tabular}{|c|c|c|c|}
\hline & & $\begin{array}{c}\text { Institutionalised } \\
\text { Environment }\end{array}$ & $\begin{array}{c}\text { Academic } \\
\text { Performance }\end{array}$ \\
\hline $\begin{array}{l}\text { Institutionalised Environ- } \\
\text { ment }\end{array}$ & $\begin{array}{l}\text { Pearson Correlation } \\
\text { Significant (2-tailed) }\end{array}$ & 1 & $\begin{array}{c}-0.200 \\
0.216\end{array}$ \\
\hline Academic Performance & $\begin{array}{l}\text { Pearson Correlation } \\
\text { Significant (2-tailed) }\end{array}$ & $\begin{array}{c}-0.200 \\
0.216\end{array}$ & 1 \\
\hline
\end{tabular}


Table 16 Pearson- Correlation of Institutionalised Environment and Learning Motivation

\begin{tabular}{llcc}
\hline & & $\begin{array}{c}\text { Learning } \\
\text { Motivation }\end{array}$ & $\begin{array}{c}\text { Institutionalised } \\
\text { Environment }\end{array}$ \\
\hline Learning Motivation & Pearson Correlation & 1 & -0.201 \\
& Significant (2-tailed) & & 0.214 \\
$\begin{array}{l}\text { Institutionalised Envi- } \\
\text { ronment }\end{array}$ & Pearson Correlation & -0.201 & 1 \\
\hline
\end{tabular}

11. Correlations between Academic Results and Extrinsic Motivation

Table 11 shows that there is a significant positive correlation between Academic Results and Extrinsic Motivation $(\mathrm{P}<0.01)$.

\section{Correlations between Academic} Results and Learning Motivation

Table 12 shows that there is a significant positive correlation between Academic Results and Learning Motivation $(\mathrm{P}<0.05)$

Therefore the results show that there is a strong relationship between Learning Motivation and Academic Performance.

13. The statistical association between Guardian Involvement and Academic Performance

Table 13 shows that there is a significant positive correlation between Academic Performance and Guardian Involvement $(\mathrm{P}<0.05)$.

Therefore, the results shows there is a relationship between Guardian Involvement and Academic Performance.

14. The statistical association between Guardian Involvement and Learning Motivation

Table 14 shows that there is no significant correlation between Learning Motivation and Guardian Involvement $(\mathrm{P}>0.05)$.

Therefore, the results show that there is no significant relationship between Learning Motivation and Guardian Involvement

15. The statistical association between Institutional Environment and Academic Performance

Table 15 shows that there is no significant correlation between Institutional
Environment and Academic Performance $(\mathrm{P}>0.05)$.

Therefore, the results show that there is no significant relationship between Institutionalised Environment and Academic Performances.

16. The statistical association between Institutionalised Environments and Learning Motivation

Table 16 shows that there is no significant correlation between Institutionalised Environments and Learning Motivation $(\mathrm{P}>0.05)$.

Therefore, the results show that that there is no significant relationship between Institutionalised Environment and Learning Motivation.

\section{Discussion}

This study investigates the relationship of Academic Performance, Learning Motivation, Institutionalised Environments and Guardian Involvement. Results of this study reveal that significant relationships exist between Academic Performance and Learning Motivation. Strong correlations between Guardian Involvement and Academic Performance also were found to exist. However relationships between Institutionalised Environments and Academic Performance, Institutionalised Environments and Learning environments and Guardian Involvement and Learning Motivation fail to exist.

The main theory that was discussed in this study was Maslow's Hierachy of Needs. According to Maslow's Hierachy of Needs the lowest level of needs is Physiological Needs. Physiological Needs refer to basic 
human needs such as food, water and clothes. The children living in this home have all their physiological needs met. The next level is Maslow's Hierachy of Needs is Safety Needs. Safety Needs refer to personal security (safe from abuse), finacial security, health and well being and safety against illness (McLeod, 2016). The children of this home have all their safety needs. They are not asked to work to pay for their neccessities as long as they are below the age of 18 . Their health is also taken care of and their personal safety is also well taken care of as caretakers are not allowed to physically harm any of the children.

The third level in Malow's Hierachy of Needs is Love and Belonging. This is the main focus for this study. Love and belonging talks about the need of an individual to belong to a family, to seek inmacy and seek friendship (McLeod, 2016). Children living in this home come from broken families. Some of them have lost either one parent to death and some have lost both. Some children were born to their unmarried mothers and have no idea who their father is while some others still have both their parents alive but due to financial constraints or some other unknown reason their parents have chose to institutionalise them. Therefore all the children that are living in this orphanage come from broken families. They have gone through many challenges. Therefore, their need to feel belonged and loved might not be met. Since results of this study show low levels of guardian involvement, this would imply that their need to feel belonged and loved were not met even after they were institutionalised.

According to Maslow, humans usually feel a sense of belonging and acceptance among their families before they start feeling it among their social groups (Maslow, 1943). Since children of this home do not have strong relationships with their caretakers, their needs to feel love and belonged are not met. This would probably be reason for their low levels of academic performance.
According to Maslow, one must satisfy lower level needs before progressing on to meet higher level needs. He adds that when a lower level need has been satisfied it no more be a need and hence one can proceed to higher level needs. The fourth level in Maslow's Hierarchy is Esteem needs. This study showed that children do not work hard to improve their academic performance which is an example of Esteem need. This is probably because their need to be love and belonged has not been fulfilled. This shows that these children do not see the need to strive for better academic performance and they will continue to not to strive to perform better academically as long as their need to feel love and belonging is not met.

Another theory that was also discussed in this study is Attachment Theory. The main idea of Attachment Theory is that an infant needs to develop a relationship with at least one primary caregiver for the child's successful social and emotional development, and in particular for learning how to effectively regulate their feelings (Holmes, 1993). Children living in this orphanage have different caregivers as it would not make sense for one person to look after a group of people for 24 hours a day. From this we can note that institutionalised children do not have a primary caregiver. Either a parent or any other individual, are equally likely to become main attachment figures provided they are giving most of the child care and relate in social interaction (Holmes, 1993).

Results showed that the levels of guardian involvement are low among institutionalised children. This could be because these children did not have a primary caregiver since they were young, and hence now they are finding it hard to become close or to build relationships with their caretakers (Holmes, 1993). The results of this study hopes to open the eyes of caretakers and staff in orphanages to help them see the importance of showing children love and care and what an impact it has on these children's academic performance. 
Although this study is done with a minority group, the results hope to show that orphans need just as much love as a mainstream child. The findings of this study hopes to show that
Maslow's Hierachy of Needs is still evident today. That it is difficult for one to strive to achieve a high self esteem when they do not feel loved and belonged (Maslow, 1943).

\section{References}

Aber, J. L., \& Allen, J. P. (1987). Effects of maltreatment on young children's socioemotional development: An attachment theory perspective. Developmental Psychology,, 23(3), 406-414.

Allport, G. (1935). Attitudes. In C. Murchison (Ed.). Handbook of social psychology, 810.

Alyssa R., G.-D. P. (2005). Examining the Relationship Between Parental Involvement and Student Motivation. Educational Psychology Review, 17(2), 99-103.

Attachment theory. (2016, July 26). Retrieved from Wikipedia, the free encyclopedia: https:// en.wikipedia.org/wiki/Attachment_theory

Baker, T. L. (1994). Doing Social Research . New York: McGraw Hill: London: UCL Press.

Bank, C. a. (1980). Successful Motivation of Students in Academic Activities in McClelland, D.C. . Appleton-Century-Crafts, 6-7.

Beatrice, J. (1995). Learning to Study through Critical Thinking. Chicago: Irwin.

Bowlby, J. (1951). Maternal care and mental health. World Health Organization Monograph, 13-53.

Candeias, A. R. (2008). Student Attitudes Toward Learning and School - Study of Exploratory Models about the Effects of Socio-demographics and Personal Attributes. RED, 35-36.

Care, O. (2015, December 17). Orphan Care. Retrieved from Conference on Destitution of Children: http://www.orphancare.org.my/index.php/category/news/

Chowa G., A. D.-A. (2012). Parental Involvement and Academic Performance in Ghana. Youth Save Research Brief, 8-9.

Christenson, S. L. (1982). Family factors and student achievement: An avenue to increase students' success. School Psychology Quarterly, 178-206.

Cohen, M. ,. (2008). Perceived parenting style, self-esteem and psychological distress in adolescents with heart disease. Psychology, Health \& Medicine, 381-388.

Darling, S. (2004). Family literacy: Meeting the needs of at-risk families. . Phi Kappa Phi Forum, 18-21. .

David R. Topor, S. P. (2010). Parent involvement and student academic performance: A multiple mediational analysis. HHS Public Access, 183-197.

Deci, E. L. (1972). Changes in intrinsic motivation as a function of negative feedback and threats. Eastern Psychological Association, 56-57.

Deci, E. L. (1998). Extrinsic rewards and intrinsic motivation: Clear and reliable effects. University of Rochester, 57-58.

Dweck, C. S. (1996). Implicit theories as organizers of goals and behavior. The psychology of action: Linking cognition and motivation to behavior, 69-90.

Entwisle DR. (1988). Lasting effects of elementary school. Sociology of Education, 147-159.

Epstein, J. L. (1997). School/Family/Community partnership. Your hand book for action. 
Thousand Oaks CA : Cowin Press.

Evens, A. (2013, March 27). Richmond Pulse. Retrieved from How Should Academic Success Be Measured?: http://richmondpulse.org/2013/03/27/how-should-academic-successbe-measured/

Fan W., \&. W. (2010). The effects of parental involvement on students' academic selfefficacy, engagement and intrinsic motivation. An International Journal of Experimental Educational Psychology, 30(1), 1.

Fantuzzo, J. M. (2004). Multiple dimensions of family involvement and their relations to behavioral and learning competencies for urban, low-income children. The School Psychology Review, 33(4), 467-480.

Fantuzzo, J. T. (2000). Family involvement questionnaire: amultivariate assessment of family participation in early childhood education. J. Educ. Psychology, 367-376.

Fredricks, B. \&. (2004). How Motivation Affects Learning Behaviour. Educational Psychology, 1.

Gabriel K. C., C. M. (2009). The self-concept and academic performance of institutionalized and non-institutionalized HIV/AIDS orphaned children in Kisumu municipality. Educational Research and Review Vol. 4 (3), 4(3), 106-110.

Gunnar, M. R. (2001). Effects of early deprivation: Findings from orphanage-reared infants and children. In N. \&. Luciana, Handbook of developmental cognitive neuroscience (pp. 617-629). Cambridge: MIT Press.

Harju, B. \&. (1997). Motivation and performance in college students enrolled in self-paced versus lecture-format remedial mathematics courses. International Trademarks, 3.

Harter, S. (1981). A new self-report scale of intrinsic versus extrinsic orientation in the classroom: Motivational and informational components. Developmental Psychology, 300-312.

Heath, S. B. (2001). Protean shapes in literacy events: Ever-shifting oral and literate traditions. . In E. \&. Cushman, Literacy: A critical Sourcebook (pp. 443-466). Boston: Bedford/St. Martin's.

Holmes, J. (1993). John Bowlby \& Attachment Theory. Makers of modern psychotherapy, 69.

Houwer, J. B.-H. (2013). What is learning? On the nature and merits of a functional. Psychon Bull Rev, 1-2.

Huitt, W. (2007). Maslow's hierarchy of needs. Educational Psychology Interactive, 23.

Huntsinger, C. S. (2009). Parental involvement in children's schooling: Different meanings in different cultures. Early Childhood Research Quarterly, 398-410.

Ilomo O., a. C. (2015). INFLUENCE OF HOME ENVIRONMENT ON STUDENTS' ACADEMIC PERFOMANCE IN SELECTED SECONDARY SCHOOLS IN ARUSHA MUNICIPALITY . Journal of Novel Applied Sciences, 1-2.

Izzo, C. V. (1999). A longitudinal assessment of teacher perceptions of parent involvement in children's education and school performance. American Journal of Community Psychology, 817-839.

Janet A. Simons, D. B. (1987). The Search for Understanding. New York: West Publishing Company.

Jeynes, W. H. (2005). A meta-analysis of the relation of parental involvement to urban 
elementary school student academic achievement. Urban Education, 40(3), 237-269.

Johnson, J. O. (1996). Child Psychology. Calabar, Nigeria: Wusen Press Limited.

Juffer F., I. M. (2007, November). Adoptees do not lack self-esteem: A meta-analysis of studies on self-esteem of transracial, international, and domestic adoptees. Psychological Bulletin, 133(6), 1067-1083.

Khan, R. \&. (1999). Effectiveness of parents' involvement in reading, child's overt behavior at home, mothers' educational level on children's reading comprehension. J. Elementary Educ, 68-91.

Kpolovie, P. J. (2014). Academic Achievement Prediction: Role of Interest in Learning and Attitude towards School. International Journal of Humanities Social Sciences and Education (IJHSSE), 13.

Krech, D. \&. (1948). Theory and problems of social psychology. New. New York: MacGrawHill.

Landa, S., \& Duschinsky, R. (2013). Crittenden's dynamic-maturational model of attachment and adaptation. Review of General Psychology, 3(17), 326-338.

Ma'rof, A. M. (2012). Promoting Emerging Literacy Skills of Malaysian Indegenious Children through Shared-Book Learning. 4.

Maclean, K. (2003). The impact of institutionalization on child development. Development and Psychopathology, 35.

Mamedova, S. \&. (2012). Early Childhood Program Participation, From the National Household Education Surveys Program of 2012. American Institutes for Research, 11.

Marinus H., I. M. (2008). IQ of Children Growing Up in Children's Homes: A Meta-Analysis on IQ Delays in Orphanages. Merrill-Palmer Quarterly, 3, 341-366.

Maslow, A. (1943). A theory of human motivation. Psychological Review, 50(4), 370-396.

McLeod, S. (2016, 12 2). Maslow's Hierarchy of Needs. Retrieved from Simply Psychology: http://www.simplypsychology.org/maslow.html

McWayne, C. H. (2004). A multivariate examination of parent involvement and the social and academic competencies of urban kindergarten children. Psychology in the Schools, 1.

Michelle M. L., K. L. (2009). Postinstitutionalized Children's Development: Growth, Cognitive, and Language Outcomes. HHS Public Asses, 426-434.

Muala. (2010, May). A study of the relationship between academic achievement motivation and home environment among standard eight pupils. Educational Research and Reviews, 5(5), 213-217.

Nair, S. (2014, July 25). The Star Online. Retrieved from thestar.com.my: http://www.thestar. com.my/lifestyle/family/features/2014/07/25/of-the-8-million-kids-in-institutionsworldwide-more-than-90percent-arent-orphans/

Nkomo, N. B. (2014). The Impact Of Orphan-Hood In The Academic Performance Of Learners . Journal of Educational studies, 46.

Olatoye RA, A. O. (2004). Emergent issues in enhancing the teaching and learning of science. Issues in educational measurement and evaluation. Adult Education Department, 23-25.

Peklaj, C. a. (2003). Students' motivation and academic success in relation to the quality of individual and collaborative work during a course in educational psychology . 
Association of Teacher Education in Europe, 10-15.

Pintrich, P. R., \& de Groot, E. V. (1990, March). Motivational and self-regulated learning components of classroom academic performance. Journal of Educational Psychology, 82(1), 33-34.

Scott, R. (1995). Institutions and organizations. . Thousand Oaks,: CA: Sage.

Scott, W. R. (2004). Institutional theory. In G. Ritzer, Encyclopedia of Social Theory (pp. 408414). Thousand Oaks,: CA: Sage.

Sengendo, J. \&. (1997). The psychological effect of orphanhood: a study of orphans in Rakai district. Health Transition Review, 8-9.

Sui-Chu, E. H. (1996, April). Effects of Parental Involvement on Eighth-Grade Achievement. Sociology of Education, 69(2), 126-141.

Ting, L. \&. (2016). The relationship between motivation for learning and academic achievement among basic and advanced level students studying Chinese as a foreign language in years 3 to 6 at Ascot International School in Bangkok, Thailand. Scholar: Au Graduate School of Education, 8(1), 10-13.

UNICEF. (2013, December 27). UNICEF. Retrieved from Malaysia Statistics: https://www. unicef.org/infobycountry/malaysia_statistics.html

UNICEF. (2016, July 14). UNICEF. Retrieved from Statistics and Monitoring: http://www. unicef.org/statistics/

University of Pittsburgh. (2005, 3 19). Office of Child Development. Retrieved from ocd.pitt. edu: http://www.ocd.pitt.edu/Default.aspx?webPageID=283

Waters, J. (2015). Correlational Research Guidelines: Conducting Correlational Research. Capilano University, 11-12. Retrieved from Correlational Research Guidelines: Conducting Correlational Research.

Wellman, B. (1998). "Doing It Ourselves: The SPSS Manual as Sociology's Most Influential Recent Book”. . Clawson, Dan: Amherst: University of Massachusetts Press. .

Whetten K, O. J. (2009). A Comparison of the Wellbeing of Orphans and Abandoned Children Ages 6-12 in Institutional and Community-Based Care Settings in 5 Less Wealthy Nations. PLoS ONE, 4(12), 5-6.

Wikipedia. (2016, August 4). Motivation. Retrieved from Wikipedia, the free encyclopedia: https://en.wikipedia.org/wiki/Motivation\#Cognitive_dissonance_theory

York, T. G. (2015). Defining and Measuring Academic Success . Practical Assessment Research and Evaluation.

Zakiyu, A. \&. (2015). A RELATIONSHIP BETWEEN PARENTAL INVOLVEMENT AND LEARNING ACHIEVMENT OF ISLAMIC EDUCATION IN NATIONAL RELIGIOUS SECONDARY SCHOOLS KUALA TERENGGANU MALAYSIA. International Conference on Empowering Islamic Civilization in the 21st Century, 6-7. 